\title{
Dehumanisasi Pada Penerapan Hukum Pidana Secara Berlebihan (overspanning van het straftrecht)
}

\author{
"Dehumanization in Excessive Application of \\ Criminal Law (Overspanning Van Het Straftrecht)"
}

\author{
Ramdhan Kasim ${ }^{1}$
}

${ }^{1}$ Fakultas Hukum Universitas Gorontalo, Indonesia. Email: ramdhankasim@gmail.com

\section{Info Artikel}

\section{Kata Kunci:}

Dehumanisasi; Hukum Pidana; Overspanning.

Cara Mengutip (APA Citation Style):

Kasim, Ramdhan. (2020).

"Dehumanisasi Pada

Penerapan Hukum Pidana Secara Berlebihan (Overspanning Van Het Straftrecht)". Jambura Law Review, JALREV 2 (1):

\begin{abstract}
Abstrak
Jika melihat kecenderungan proses penerapan pemidanaan di Indonesia, maka dapat kita lihat bahwasanya banyak proses pemidanaan yang diterapkan secara berlebihan. Tentunya hal ini menyebapkan adanya over ciminalization pada penerapan pemidanaan yang menyebapkan adanya ketidak harmonisan dalam penerapan hukum pidana, dimana meniadakan rasa kemanusiaan yang berujung pada banyak gejala dehumanisasi yang terjadi. Pada penelitian ini mengunakan jenis jenis penelitian hukum normatif dengan mengunakan Pendekatan Perundang-Undangan (Statue Approach), Pendekatan konseptual (Conseptual Approach), dan pendekatan kasus (case Approach). Penelitian ini bertujuan untuk mengetahui Bagaimana penerapan hukum pidana yang ada di Indonesia saat ini dan Bagaimana Prospektif hukum pidana dan pemidanaan yang ada di Indonesia. Hasil penelitian ini menunjukkan Bahwa penerapan hukum pemidanaan di Indonesia saat ini, masih meninggalkan beberapa catatan penting antara lain; banyak Terjadinya Over Criminalization dan banyaknya terjadi Dekonstruksi Pidana dan Pemidanaan di Indonesia dimana dekonstruksi itu antara lain; Pertama, Terjadinya Over Kapasitas Lapas dan Rutan, kedua, Pengaturan Hukuman Mati yang Sangat Massif; ketiga, Kebijakan Hukum Yang Over Pada Penghinaan Di Media Sosial; keempat, Dalam Penyidikan Kriminal Penyidik Mencari Bukti Dengan Kejahatan (penyiksaaan); kelima, Inkonsistensi Hak Atas Perkara CumaCuma (prodeo). Bahwa Prospektif Pembaharuan Hukum Pidana dan Pemidanaan Yang Ada di Indonesia harus didasarkan pada beberapa hal, antara lain: Pedekatan Restorative Justice dalam Penerapan Pemidanaan; Pendekatan Ultimum remedium dalam penerapan pemidanaan; Reformasi Kelembagaan Lembaga Penegak Hukum; dan Revisi Kitab Undang-Undang
\end{abstract}


Volume 2 Issue 01

JALREV 2 (1) 2020
January 2020

ISSN Print : :2654-9266

ISSN Online : 2656-0461

\section{Article Info}

\section{Keywords:}

Dehumanization; Criminal Law;

Overspanning.

How to cite (APA Citation Style):

Kasim, Ramdhan. (2020).

"Dehumanization in Excessive Application of Criminal Law (Overspanning Van Het Straftrecht)". Jambura Law Review, JALREV 2 (1):
Hukum Pidana (KUHP) dan Kitab Undang-Undang Hukum Acara Pidana (KUHAP).

\begin{abstract}
If you look at trends in the application of criminal justice in Indonesia, we can see that many criminal processes are over-applied. Obviously this results in overciminalization in the application of punishment which results in disharmony in the application of criminal law, which negates humanity which results in many symptoms of dehumanization that occur. In this study using the type of normative legal research using the Legislative Approach (Statue Approach), Conseptual Approac), and case Approach. This study aims to determine how the application of criminal law in Indonesia today and how prospective criminal law and criminal law in Indonesia. The results of this study indicate that the application of criminal law in Indonesia today, still leaves several important notes, among others; a lot happened Over Criminalization and a lot happened Criminal Deconstruction and Criminal Justice in Indonesia where deconstruction among others; First, the occurrence of overcapacity in prisons and detention centers, second, the regulation of a very massive death sentence; third, Legal Policies Over Humiliation on Social Media; fourth, in criminal investigations investigators look for evidence with crime (torture) fourth, in criminal investigations investigators look for evidence with crime (torture); Fifth, Inconsistency of Free Right to Case (Prodeo). That the Prospective Reform of Criminal Law and Criminal Existing in Indonesia must be based on several things, among others: Restorative Justice Approach in Criminal Application; Ultimum remedium approach in the application of punishment; Institutional Reform of Law Enforcement Agencies; and Revision of the Criminal Code (KUHP) and the Criminal Procedure Code (KUHAP).
\end{abstract}




\section{Pendahuluan}

Saat ini, tidak hanya tingkat kejahatan atau kuantitas kejahatan yang semakin meningkat namun juga jenis kejahatan atau kualitas telah berkembang dengan pesat di Indonesia. Sanksi pidana dipandang sebagai solusi yang efektif dalam menanggulangi masalah tersebut. Sanksi pidana merupakan wujud tanggung jawab negara untuk menjaga keamanan dan ketertiban serta upaya perlindungan hukum bagi warganya. Hal ini merupakan konsekuensi logis dari konsep pembentukan sebuah negara yang menurut JJ Rosseau, didasarkan pada perjanjian masyarakat. Selanjutnya rakyat bersepakat mengadakan sebuah perjanjian luhur (modus vivendi) yang dituangkan dalam sebuah hukum dasar berwujud konstitusi negara. ${ }^{1}$

Salah satu bentuk pengaturan hukum sebagai instrumentasi penegakan hukum dalam kehidupan berbangsa dan bernegara diatur di dalam KUHPidana. Ketentuan- ketentuan pemidanaan yang dikondifikasikan dalam bentuk Kitab Undang Undang Hukum Pidana atau yang biasa disingkat dengan KUHPidana ini diharapkan dapat menghadirkan proses penegakan hukum yang sesuai dengan cita negara hukum indonesia. Namun, dalam prakteknya ketentuan pemidanaan di Indonesia lebih mengedepankan sanksi sebagai solusi dalam menekan angka kriminalitas, tentunya hal ini bukan hal yang tidak asing lagi dalam praktek hukum pidana yang ada di Indonesia, sebagaimana yang kita ketahui bahwa KUHPidana yang saat ini digunakan adalah peninggalan kolonial yang aslinya bernama Wetboek van Strafrecht voor Nederlandsch Indie (WvS-NI). KUHP ini pertama kali diberlakukan di Indonesia pada tanggal 1 Januari 1918 berdasarkan Koninklijk Besluit (Titah Raja) Nomor 33 tertanggal 15 Oktober 1915. Pasca kemerdekaan, untuk mengisi kekosongan hukum pidana, maka berdasarkan Pasal II Aturan Peralihan UUD 1945, WvS-NI

1 Titin anidyajati, dkk, (2015). "Konstitusionalitas Norma Sanksi Pidana sebagai Ultimum Remedium dalam Pembentukan Perundang-undangan". Jurnal Konstitusi, Volume 12 Nomor 4 Desember: 874 
tetap diberlakukan berdasarkan UU No. 1 Tahun 1946 tentang Peraturan Hukum Pidana Indonesia. Padahal di negara asalnya (Belanda) Kitab Undang Undang Hukum Pidana mereka telah beberapa kali dilakukan perubahan untuk menyesuain dengan tuntutan perubahan zaman, dengan penedekatan pemidanaan modern.

Ketentuan pemidanaan yang masih menjiwai KUHPidana Indonesia tidak terlepas dari sifatnya yang masih dalam pengaruh produk peninggalan kolonial belanda ini seharusnya dan sudah sepantas segera untuk mendapatkan perubahan secara subtantif dan disesuaikan dengan pendekatan teori pemidaanaan modern saat ini, hal perlu dilakukan, mengigat usia KUHPidana kita saat ini yang lagi muda dan yang pasti benyak ketentuan pemidanaan yang diatur didalamnya juga tdak lagi sesuai dengan kondisi saat ini. Termasuk yang menjadi catatan penting untuk dilakukan perubahan adalah, bahwa sifat KUHPidana Indonesia adalah sangat refresif lebih menekangkan pada sanksi ketimbang rekonsiliasi sebagai bentuk penindakan preventif dimana menempatkan ketentuan sanksi diakhir dan bukan sebagi pilar utama atau dalam teori pemidanaan saat ini dikenal dengan istilah Ultimum remedium. Oleh karena itu, maka seharusnya dalam penegakan hukum pidana yang ada di negara kita saat ini mengedepankan beberapa pendekatan melalui prinsip ultimum remedium yang artinya pemidanaan ditempatkan paling terakhir dalam memberikan sanksi kepada pelaku tindak pidana.

Tatanan instrumen hukum pidana dan pemidanaan di Indonesia telah mengatur mengenai prosedur formal yang harus dilalui dalam menyelesaikan sebuah perkara pidana. Namun sayangnya sistem formil tersebut dalam praktiknya sering digunakan sebagai alat represif bagi mereka yang berbalutkan atribut penegak hukum. Memang segala tindak kejahatan harus dihukum sesuai dengan aturan dan perundang-undangan 
yang berlaku. Namun ada kalanya, hukum yang diberlakukan tidak tepat sasaran atau dapat dikatakan tumpul ke atas dan hanya mencederai masyarakat golongan bawah saja yang oleh penulis sendiri lebih memilih mengunakan kata "Dehumanisasi" dalam mengambarkan fenomena penegakan hukum yang ada di negara Indonesia saat ini. Banyak kasus yang terjadi di Indonesia, mulai dari yang bersifat sepele sampai dengan yang bertaraf tinggi dan perlu diproses secara ketat. Khususnya untuk yang bersifat sepele, tidak sedikit para pelakunya adalah 'wong cilik' yang buta akan hukum dan akhirnya menjadi bulan-bulanan di pengadilan karena ketidaktahuannya dan juga faktor lain walaupun sanksi kejahatannya dapat dikatakan sangat ringan.

Dari kunjungan Pakar Hukum Pidana Prof. Andi Hamzah, ternyata 60\% perkara yang ditangani jaksa di Belanda diselesaikan melalui penyelesaian perkara di luar pengadilan (afdoening buiten process). Sedangkan, di Indonesia yang menganut Asas Legalitas dapat dikatakan 99\% perkara yang ada di tahap pra penuntutan pada akhirnya dilimpahkan ke pengadilan. ${ }^{2}$ Jika berkaca pada proses penyelesaian kasus tindak pidana antara Indonesia dan Belanda, maka kita dapat melihat adanya garis demarkasi yang besar antara proses penyelesaian tindak pidana antara Indonesia dengan belanda yang notabene merupakan induk dari system hukum pidana di Indonesia.

Dengan melihat adanya pemidanaan yang kadang kalah berlebihan dalam system pemidanaan di negara kita, maka ada potensi dehumanisasi yang besar jika dalam aspek aktualisasi dari system pemidaanaan yang ada saat ini dipertahankan, oleh karena itu, maka

2 Albert Aries. (2018). "Penerapan Hukum Pidana Berlebihan". Dilansir dari https://www.kulitinta.id/2018/08/13/penerapan-hukum-pidana-yang-berlebihan/ . Diakses pada 20 Januari 2019. 
penulis tertarik untuk melakukan analsisis hukum tentang potensi Dehumanisasi pada penerapan hukum pidana secara berlebihan (Overspanning Van Het Straftrecht).

\section{Rumusan Masalah}

Berdasarkan latar belakang di atas, maka penulis merumuskan beberapa rumusan masalah yang akan menjadi kajian utama dari penulis. Adapaun rumusan masalahnya adalah Bagaimana penerapan hukum pidana yang ada di Indonesia saat ini dan Bagaimana Prospektif hukum pidana dan pemidanaan yang ada di Indonesia.

\section{Metode}

Metode penulisan yang digunakan oleh peneliti dalam menyusun penelitian ini yaitu jenis penelitian hukum normatif. Penelitian hukum normatif yang di maksud yaitu penelitian yang objek kajiannya meliputi norma atau kaida dasar, asas-asas hukum, peraturan perundangundangan, perbandingan hukum, doktrin serta yurisprudensi. Adapun pendekatan penelitian yang digunakan oleh peneliti dalam menyusun penelitian ini adalah; Pendekatan Perundang-Undangan (Statue Approach), Pendekatan konseptual (Conseptual Approach), dan pendekatan kasus (case Approach).

\section{Penerapan Hukum Pemidanaan di Indonesia.}

Andi Hamzah memberikan arti sistem pidana dan pemidanaan sebagai susunan (pidana) dan cara pemidanan. Sedangkan M. Sholehuddin menyatakan, bahwa masalah sanksi merupakan hal yang sentral dalam hukum pidana karena seringkali menggambarkan nilai-nilai sosial budaya suatu bangsa. Artinya pidana maengandung tata nilai (value) dalam suatu 
masyarakat mengenai apa yang baik dan yang tidak baik, apa yang bermoral dan apa yang amoral serta apa yang diperbolehkan dan apa yang dilarang. ${ }^{3}$

Dengan demikian dapatlah diartikan bahwa pemidanaan tidak dapat terlepas dari jenis-jenis pidana yang diatur dalam hukum positif suatu negara. Pemidanaan yang dilakukan oleh suatu masyarakat yang teratur terhadap pelaku kejahatan dapat berbentuk menyingkirkan atau melumpuhkan para pelaku tindak pidana, sehingga pelaku tersebut tidak lagi menggangu di masa yang akan datang. Cara menyingkirkan atau melumpuhkan dapat dilakukan bermacam-macam yaitu berupa pidana mati, pembuangan, pengiriman keseberang lautan dan sampai pemenjaraan. Secara berangsur-angsur ada kecenderungan cara pemidanaan itu mengalami pergeseran dari waktu ke waktu.

Pada zaman kerajaan majapahit dikenal sistem pemidanaan berupa; pidana pokok yang meliputi pidana mati, pidana potong anggota badan bagi yang bersalah, denda, ganti kerugian, atau pangligawa atau putukucawa. Dan juga dikenal pidana tambahan yang meliputi tebusan, penyitaan dan patibajambi (uang pembeli obat). ${ }^{4}$ jika kita melihat secara mendalam akan kita temukan bahwa dalam kitab perundang -undangan Majapahit sama sekali tidak mengenal pidana penjara dan pidana kurungan. Dengan demikian tiap-tiap orang yang bersalah harus menjalani salah satu dari empat pidana pokok sebagaimana yang telah diatur di dalam kitab undang undang kerajaan majapahit tanpa adanya pemidanaan penjara dan kurungan.

3 Ekaputra, Mohammad dan Abul Khair. (2010). “Sistem Pidana Di Dalam KUHP Dan Pengaturannya Menurut Konsep KUHP Baru”. Medan: USU Press. Hal. 13.

4 Andi Hamzah dan Siti Rahayu. (1986). "Suatu Tinjauan Ringkas Sistem Pemidanaan Di Indonesia”. Jakarta: Akademik Pressindo. Hal. 4. 
Berbeda dengan keadaan Majapahit, untuk kondisi atau keadaan sekarang sistem pemidanaan telah mengalami banyak perubahan-perubahan yang berupa penyempurnaan dari sistem yang telah lalu. Tidak terlepas pula dengan keadaan di Indonesia, sistem pemidanaan yang ada berlaku hingga sekarang masih mengacu pada KUHPidana yang merupakan warisan Kolonial Belanda. Dari sistem ini yang tercantum dalam Kitab UndangUndang Hukum Pidana tersebut banyak menimbulkan permasalahan, diantaranya mengenai relevansinya sistem pemidanaan yang dipakai dewasa ini dengan keadaan atau kondisi bangsa Indonesia. Berikut gambaran penerapan pidana di Indonesia menurut penulis:

\section{a. Terjadinya Over Criminalization}

Kriminalisasi menurut Nina Persak" adalah "defining certain human conduct (acts or omissions) as criminal offences and usually assign-ing to them a certain range of criminal law sanctions." Berdasarkan Pasal 1 ayat (1) Kitab Undang-undang Hukum Pidana (KUHP) yang lebih dikenal sebagai asas legalitas, suatu tindakan hanya dapat dikualifikasi sebagai tindak pidana manakala negara telah melakukan kriminalisasi terhadap tindakan tersebut melalui undang-undang (legislasi). ${ }^{6}$

Pernyataan ini dapat dikaitkan dengan konsep negara hukum sebagaimana dijelaskan oleh Brian Z. Tamanaha. Menurut Tamanaha7, secara konseptual the Rule of Law atau negara hukum memiliki "to impose legal restraints on government officials." Fungsi ini dilakukan dengan dua cara. Pertama, government offficials must abide by valid positive laws in force at

5 Nina Persak. (2007). "Criminalising Harmful Conduct: The Harm Principle, Its Limits and Continental Counterparts".New York: Springer. Hal. 6.

6 Marthen H. Toelle. (2015). "Kriminalisasi Berlebih (Overcriminalization) Dalam Kriminalisasi Korupsi". Jurnal Refleksi hukum, Vol. 9. No. 2: 113

7 Brian Z. Tamanaha. (2009). "A Concise Guide of the Rule of Law' dalam Gianluigi Palombella dan Neil Walker, eds., Relocating the Rule of Law". England: Hart Publishing. Hal. 4 
the time of any given action. Konsekuensi yang kemudian timbul: "government actions must have positive legal authorization (without which the action is improper); and no government action may contravene a legal prohibition or restriction. Tetapi meskipun negara yang membuat peraturan perundang-undangan, tidak berarti negara tidak terikat olehnya. Cara kedua, "imposes restrictions on the law itself, erecting limitations on the law-making power of the government." Konsekuensinya ialah":

certain prohibited actions cannot be legally allowed, even by a legitimate lawmaking authority. Legal restrictions of this sort rank above (control over) ordinary law-making. The most familiar versions of this are: 1) constitutionally imposed limits, 2) transnational or international legal limits, 3) human rights limits, and 4) religious or natural law limits. In different ways and senses, these types of law are superior to and impose restraints upon routine law making. ${ }^{9}$

Dalam pendapat tersebut Persak memberikan satu penekanan penting bahwa tindakan kriminalisasi harus didasari oleh legitimate or justifiable reasons yang disebut dengan istilah principles for criminalisation. Berdasarkan pendapat tersebut, principles for criminalisation bertumpu pada konsep pembatasan terhadap kekuasaan negara/pemerintah dengan bertolak dari gagasan otonomi atau kebebasan individu.

Beberapa catatan penting dalam perjalan sejarah penegakan hukum di Indonesia meninggalkan sejumlah lorong gelap yang sangat tidak sesuai dengan semangat pemidanaan modern yang berkembang saat ini. Banyakya terjadi kriminalisasi secara berlebihan meruapakan pintu baru bagi timbulnya kesengsaraan di tengah masyarakat contoh sederhana misalnya, pada saat masyarakat ingin menyuarakan kepentinganya di depan

8 Ibid, Hal. 4-5

9 Ibid, Hal. 5 
umum, akan tetapi langkah itu bagi aparat penegak hukum dinilai melanggar hukum sehingga berujung pada pemidanaan.

\section{b. Dekonstruksi Pidana dan Pemidanaan di Indonesia}

\section{1) Terjadinya Over Kapasitas Lapas dan Rutan}

Merupakan suatu fakta umum (notoir feiten) yang sulit dibantah bahwa kondisi dari sebagian lapas di Indonesia sudah jauh dari semangat memasyarakatkan terpidana. Kondisi ini senyatanya tidak dapat dibebankan sepenuhnya pada Dirjen Pemasyarakatan yang berada di bawah naungan Kemenkumham. Adanya pola penitipan tahanan sementara di rumah tahanan (rutan), banyaknya pidana penjara yang dijatuhkan pada kasus "orang kecil", dan dihukumnya pelaku tindak pidana yang ancaman hukuman di bawah 5 tahun (lichte misdrijven) telah membuat rutan dan lapas menjadi over kapasitas.

Menteri Hukum dan Hak Asasi Manusia, Yasonna H Laoly, mengakui kondisi lembaga pemasyarakatan di Indonesia memang sangat memprihatinkan. Menurutnya Yasonna $\mathrm{H}$ Laoly persoalan utama datang dari kelebihan kapasitas dan keterbatasan sumber daya manusia. ${ }^{10}$

Mengenai permasalahan overkapasitas Lapas dan Rutan dapat dilihat melalui tabel dibawah ini $^{11}$ :

10 Sindonews Nasional. "Menkumham Curhat Banyak Lapas Over Kapasitas. Dilansir dari http://nasional.sindonews.com/read/944402/13/menkumham-curhat-banyak-lapas-over-kapasitas1420005464 . Diakses pada 20 januari 2019.

11 Anggara dkk. (2015). "Laporan Situasi Reformasi Hukum Di Sektor Pidana Indonesia (Catatan Di 2014 Dan Rekomendasi Di 2015)". Jakarta: Institute for Criminal Justice Reform. Hal. 8 
Volume 2 Issue 01

JALREV 2 (1) 2020
January 2020

ISSN Print : 2654-9266

ISSN Online : 2656-0461

\begin{tabular}{ccccc}
\hline Jumlah & Desember & Desember & Desember & Januari \\
& $\mathbf{2 0 1 2}$ & $\mathbf{2 0 1 3}$ & $\mathbf{2 0 1 4}$ & $\mathbf{2 0 1 5}$ \\
\hline Tahanan & 8.309 & 51.293 & 52.922 & 53,014 \\
\hline Narapidana & 102.379 & 108.668 & 110.482 & 111.845 \\
\hline UPT & 440 & 459 & 63 & 464 \\
\hline Kapasitas & 102.040 & 107.359 & 109.573 & 110.098 \\
\hline Overcapacity (\%) & $148 \%$ & $149 \%$ & $149 \%$ & $150 \%$ \\
\hline
\end{tabular}

Dari tabel tersebut dapat dilihat bahwa peningkatan angka tahanan dan narapidana terjadi tiap tahunnya, meskipun jumlah UPT dan kapasitas juga bertambah, namun tentu saja tidak dapat membendung lonjakan penghuni Rutan dan Lapas. Tercatat pada Desember 2012 terdapat 440 UPT dengan kapasitas penghuni mencapai 102.040 orang, jumlah narapidana dan tahanan mencapai 150.688 orang, mengakibatkan overkapasitas mencapai 148\%. Angka tersebut kemudian meningkat sampai dengan Desember 2013, dengan peningkatan jumlah UPT mencapai 459 UPT, overkapasitas tetap terjadi dan meningkat menjadi 149\%. Angka overkapasitas sebesar 149\% bertahan di Desember 2014, meskipun terjadi penambahan UPT menjadi 463 dan kapasitas menjadi 109.573 penghuni. Pada data terakhit melalui SDP Ditjen Pas, Januari 2015, overkapasitas meningkat menembus angka 150\%, hal tersebut dikarenakan jumlah penghuni Rutan dan Lapas yang mencapai 164.859 orang, berbanding kapasitas 464 UPT yang hanya mampu menampung 110.098 penghuni.

Overkapasitas tentu saja menjadi masalah yang sangat mendasar yang menjadi alasan utama dari berbagai persoalan di Rutan dan Lapas. Ada beberapa masalah yang diamati oleh penulis yang merupakan dampak langsung dari persoalan overkapasitas. Dengan melihat angka di atas, jelas memperlihatkan bagaimana tidak proporsionalnya sistem pemidanaan yang ada dengan infarstruktur pendukungnya, sehingga yang terjadi bukan lagi bukan justru 
rehabilitas melainkan memunculkan masalah dan persoalan baru yang tentu saja hal ini telah menyebapkan terjadinya bentuk pelangaran hak asasi manusia dan memberikan citra buruk terhadap Indonesia yang di anggap sangat berlebihan dalam penerapan pidana dan pemidanaan dan beujung pada terjadinya dehumanisasi pada penerapan hukum pidana secara berlebihan (Overspanning Van Het Straftrecht).

Oleh karena itu, maka kedepannya sistem pemidanaan sudah harus dirubah dengan cara yang lebih humanistis. Mengenai perubahan ini bisa saja melakukan studi perbandingan ke negara Belanda. Meskipun tidak dapat dibandingkan secara apple to apple (dari segi budaya hukum dan jumlah penduduk), hasil yang dicapai oleh pemerintah Belanda dalam menutup 19 lapas karena kekurangan pelaku kejahatan patut untuk ditiru oleh Indonesia. Misalnya, dengan mengubah pola pemidanaan dari menghukum menjadi rehabilitasi, kerja sosial, denda; dan, pemasangan gelang kaki bagi napi sehingga tetap dapat bergaul di masyarakat.

\section{2) Pengaturan Hukuman Mati yang Sangat Massif}

Hukuman Mati di Indonesia selalu memantik dan menimbulkan kontroversi yang cukup keras tidak hanya datang dari dalam negeri akan tetapi kritik yang cukup keras juga datang dari luar negeri. Para pegiat Hak Asasi Manusia memandang pengaturan dan penerapan hukuman mati justru bertentangan dengan hak hidup ${ }^{12}$. Hukuman Mati di Indonesia masih merupakan bagian dari pidana pokok atau pidana utama yang diatur dalam Kitab UndangUndang Hukum Pidana (KUHP). ${ }^{13}$ Dalam KUHP sendiri ada Sembilan jenis kejahat yang diancam dengan hukuman mati yaitu:

1. Makar dengan maksud membunuh presiden dan wakil presiden (Pasal 104 KUHP);

12 Lihat Pasal UDHR, ICCPR, UUD 1945, UU No 39 Tahun 1999 tentang Hak Asasi Manusia

13 Lihat Pasal 10 huruf a angka 1 Kitab Undang undang Hukum Pidana 
2. Melakukan hubungan dengan negara asing sehingga terjadi perang (Pasal 111 Ayat 2 KUHP);

3. Pengkhianatan memberitahukan kepada musuh di waktu perang (Pasal 124 Ayat 3 KUHP);

4. Menghasut dan memudahkan terjadinya huru-hara (Pasal 124 bis KUHP);

5. Pembunuhan berencana terhadap kepala negara sahabat (Pasal 140 Ayat 3 KUHP);

6. Pembunuhan berencana (Pasal 340 KUHP);

7. Pencurian dengan kekerasan secara bersekutu mengakibatkan luka berat atau mati (Pasal 365 Ayat 4 KUHP);

8. Pembajakan di laut mengakibatkan kematian (Pasal 444 KUHP);

9. Kejahatan penerbangan dan sarana penerbangan (Pasal $149 \mathrm{~K}$ Ayat 2 dan Pasal 1490 Ayat 2 KUHP).

Selain di KUHP, hukuman mati juga diatur oleh beberapa peraturan perundang-undangan di antaranya adalah:

1. Tindak Pidana Ekonomi (UU No 7/Drt/ 1955);

2. Tindak Pidana Narkotika (UU No 35 Tahun 2009);

3. Tindak Pidana Korupsi (UU No 31 Tahun 1999 sebagaimana telah diubah dan ditambah dengan UU No 20 Tahun 2001);

4. Tindak Pidana terhadap Hak Asasi Manusia (UU No 39 tahun 1999);

5. Tindak Pidana Terorisme (UU Nomor 15 tahun 2003).

Dasar hukum dari hukuman mati ini juga pernah diuji di Mahkamah Konstitusi (MK). Tercatat, setidaknya dua kali MK memutuskan konstitusionoialitas hukuman mati, pertama yaitu tentang pidana hukuman matinya yang dianggap masih sesuai dengan UUD $1945^{14}$ dan

14 Lihat Putusan MK No 2-3/PUU-V/2007 tertanggal 30 Oktober 2007 http://www.mahkamahkonstitusi.go.id/putusan/putusan_sidang_Putusan\%2023\%20PUUV2007ttgPidana\% 20Mati300ktober2007.pdf. 
kedua mengenai tata cara pelaksanaan hukuman mati yang juga dipandang tidak bertentangan dengan UUD 1945. ${ }^{15}$

Dengan melihat sebaran peraturang perundang undangan yang mengatur tentang pidana mati masih sangat massif diberlakukan di Indonesia, tentunya hal ini menggambarkan bahwa telah terjadi ketidak harmonisan dengan tujuan pemidanaan modern yang saat ini telah menjadi landmark decision pemidanaan di berbagai negara-negara di dunia.

\section{3) Kebijakan Hukum Yang Over Pada Penghinaan di Media Sosial}

Dalam penelusuran yang dilakukan oleh penulis dengan menggunakan metode riset secara kepustakaan ditemukan setidaknya 16 kasus pemidanaan terhadap penguna media sosial. Kasus itu antara lain Prita Mulyasari ${ }^{16}$, Narliswani Piliang17, Ujang ${ }^{18}$, Nur Arafah ${ }^{19}$, Ibnu Rachal Farhansyah ${ }^{20}$, Yan Sofyan ${ }^{21}$, Indra Bn ${ }^{22}$, Budimann ${ }^{23}$, Denny Indrayana ${ }^{24}$, Farhat

15 Lihat Putusan MK No 21/PUU-VI/2008 tertanggal 21 Oktober 2008, http://hukum.unsrat.ac.id/mk/mk_21_2008.pdf

16 Prita mulyasari ditahan karena email keluhkan layanan RS

17 Pada november 2008, narliswani (iwan) piliang, seorang pewarta warga dilaporkan anggota dpr alvin lie karena menulis artikel berita di presstalk.info berjudul 'hoyak tabuik adaro dan soekanto'.

18 Melakukan pencemaran nama baik melalui facebook.

19 Nur arafah atau farah, seorang pelajar sma asal bogor, divonis 2 bulan 15 hari dengan masa percobaan 5 bulan lantaran terbukti menghina felly fandani via facebook

20 Kasus ini terjadi pada 16 maret 2010 silam. Status facebook ibnu rachal farhansyah memicu kemarahan masyarakat bali, yang mayoritas beragama hindu. Sebab di saat mayoritas masyarakat bali menggelar ritual nyepi, ibnu malah menulis status yang memicu konflik

21 Menghina bupati pasbar baharuddin $r$ dengan kata-kata kotor. Lewat tulisan tersebut, pelaku diduga sengaja mencemarkan nama baik bupati pasaman barat tersebut ditambah lagi dengan menyebarluaskannya di media internet.

22 Kasus pencemaran nama baik

23 Kasus penghinaan Bupati Pangkep, Sulsel, Syamsuddin Hamid Batara.

24 Kasus pencemaran nama baik dan penghinaan 
Abbas $^{25}$, Bondan Prakoso ${ }^{26}$, Said Ruhpina ${ }^{27}$, Deni Irawan ${ }^{28}$, Irsyad ${ }^{29}$, Yunius Koi Asa ${ }^{30}$, dan Florence Sihombing ${ }^{31}$.

Jika mencermati kasus diatas hampir semuanya dijerat dengan UU No 11 Tahun 2008 tentang Informasi dan Transaksi Elektronik. Sejak kelahirannya, UU No 11 Tahun 2008 tentang Informasi dan Transaksi Elektronik telah menuai banyak sekali kontroversi dan kritik. Kritik tersebut khususnya ditujukan terhadap perumusan ketentuan pidana yang terkait dengan larangan penyebaran informasi elektronik yang bermuatan; (i) kesusilaan, (ii) penghinaan dan/atau pencemaran nama baik, dan (iii) materi yang mengandung materi SARA, serta tingginya ancaman hukuman terhadap larangan tersebut, baik berupa pidana penjara maupun denda.

Menurut penulis, Ketentuan pidana dalam UU ITE dirumuskan secara sangat longgar, multitafsir dan tidak jelas membuat begitu mudahnya setiap pendapat dan ekspresi dilaporkan ke polisi akibat dianggap menghina, mencemarkan nama baik, menodai agama atau ungkapan SARA lainnya. Ancaman pidana penjara yang tinggi telah berdampak pada

25 Kasus penghinaan terhadap Basuki Tjahaja Purnama alias Ahok

26 Tuduhan pencemaran nama, kasus ini terjadi pada pada 23 April 2011.

27 Kasus ini terjadi pada bulan Februari 2013 dimana Prof. Said Ruhpina, Rektor IKIP Mataram, NTB melaporkan dosen Bahasa Inggris Fakultas Pendidikan Bahasa dan Sastra Institut Keguruan dan Ilmu Pendidikan Mataram atas tuduhan pencemaran nama baik.

28 dilaporkan oleh Fadlin Akbar, anak mantan Wali Kota Tangerang, Wahidin Halim ke Polres Metropolitan Tangerang. Deni dilaporkan lantaran status BBM-nya yang dianggap mencemarkan nama baik Fadlin Akbar.

29 Kasus pencemaran nama baik dan penghinaan

30 Direktur Yayasan Abdi Masyarakat dan Alam Lingkungan (AMAL) Kabupaten Belu, Nusa Tenggara Timur, Yunius Koi Asa, dilaporkan ke Polres Belu, 16 Maret 2013 lalu oleh Silverius Mau, koordinator Program Anggaran Menuju kesejahteraan (Anggur Merah).Yunius dilaporkan gara-gara mengungkap kecurangan dalam Pemilihan Gubernur dan Wakil Gubernur Nusa Tenggara Timur melalui jejaring sosial Facebook dan tiga media cetak harian lokal.

31 Mahasiswi pascasarjana UGM, ditahan penyidik Polda DIY lantaran dianggap menghina Yogyakarta lewat status di media sosial Path. 
mudahnya penegak hukum untuk melakukan tindakan penahanan. UU ITE dalam penegakannya, meski mengatur secara khusus hukum acaranya, namun prosedur umumnya masih bersandar pada KUHAP, termasuk dalam prosedur penahanan.

Selain itu juga, di dalam pasal 27 ayat (3) UU No 11 Tahun 2008 tentang Informasi dan Transaksi Elektronik tidak diperlukan alasan pembenar, inilah yang menjadi akar masalahnya sehingga seakan-akan doktrin membela diri dan alasan pembenar tidak ada dalam rumusan Pasal 27 ayat (3) ITE. Sementara Menurut hukum Indonesia, baik dalam hukum pidana maupun hukum perdata, hanya ada satu alasan yang dapat digunakan untuk membela diri dalam perkara penghinaan. Alasan tersebut diatur dalam Pasal 310 ayat (3) KUHP dan Pasal 1376 KUHPerdata. Pentingnya alasan pembenar ini ditegaskan dalam Pasal 19 ayat (3) Kovenan Sipol yang telah meletakkan syarat-syarat dasar tentang hal tersebut.

\section{4) Dalam Penyidikan Kriminal Penyidik Mencari Bukti Dengan Kejahatan (penyiksaaan)}

Polisi sebagai pihak yang paling banyak melakukan penyiksaan maupun kekerasan terkonfirmasi berdasarkan 2.200 laporan yang diterima Komnas HAM terkait dugaan pelanggaran HAM yang dilakukan oleh anggota Polri sepanjang 2014, angka ter nggi kekerasan dalam proses penyidikan dan BAP ${ }^{32}$. Alasan untuk mendapatkan pengakuan mendominasi modus dilakukannya penyiksaan, berbarengan dengan alasan penghukuman yang dilakukan oleh aparat negara. Sejauh ini, berdasarkan pengamatan ICJR, penegakan hukum terhadap kasus-kasus penyiksaan dalam tahapan proses peradilan sangat minim,

32 Detik News. "Polri Bnayak diadukan Komnas HAM Desak Pembentukan Anti Penyiksaan" Diakses dari Dilansir dari http://news.detik.com/read/2015/01/08/144548/2797743/10/polri-banyak-diadukankomnas-ham-desak-pembentukan-uu-anti-penyiksaan . Diakses pada 21 januari 2019. 
para pelaku masih susah untuk diadili atau cenderung dilindungi oleh instansi masingmasing. 33

Merujuk pada sebaran wilayahnya, berdasarkan hasil pemantauan ICJR, Provinsi Sumatera Utara menjadi wilayah dengan tingkat penyiksaan tertinggi sebanyak 6 kasus. Urutan kedua ditempati oleh Sumatera Barat dan Jakarta yang masing-masing sebanyak 4 kasus. Urutan berikutnya tersebar diberbagai wilayah seperti Aceh, Jawa Barat, Jawa tengah, Jawa Timur, Tangerang, Papua, Maluku, Riau, Lampung, Papua dan Sulawesi Selatan dengan masingmasing terdapat 3 sampai 1 kasus. ${ }^{34}$

\section{5) Inkonsistensi Hak Atas Perkara Cuma-Cuma (Prodeo)}

Bantuan Hukum sebagai bagian dari hak asasi manusia telah lama dikenal dalam sejarah ketatanegaraan Indonesia. UUD 1945 sebelum proses amandemen secara implisit mengakui hak atas bantuan hukum sebagai bagian dari prinsip persamaan di muka hukum. ${ }^{35}$ Berdasarkan ketentuan-ketentuan dalam UUD 1945, pada dasarnya setiap orang dijamin haknya atas peradilan yang adil dan tidak memihak. Pada dasarnya suatu proses hukum yang adil dalam suatu sistem peradilan pidana tidak akan dapat diwujudkan tanpa memberikan perlindungan terhadap hak-hak tersangka dan juga terdakwa. Untuk itu diperlukan jaminan hak atas bantuan hukum yang melindungi hak tersangka dan terdakwa untuk sebagai langkah awal untuk mendapatkan peradilan yang adil dan tidak memihak. Bantuan hukum, utamanya dalam sistem peradilan pidana, dijamin sebagai bagian dari

33 Anggara dkk. (2015). Op.cit, Hal. 19

34 Ibid

35 Lihat Pasal 27 ayat (1) UUD 1945 
kerangka hak konstitusional warga Negara untuk mendapatkan akses terhadap keadilan dalam rangka menghadapi kekuatan dan kewenangan yang dimiliki oleh Negara.

Kerangka pengaturan hak atas bantuan hukum dalam sistem peradilan pidana diatur secara khusus dalam Pasal 56 KUHAP. Berdasarkan ketentuan tersebut, setiap orang miskin yang diancam dengan ancaman pidana penjara diatas 5 tahun wajib diberikan hak atas bantuan hukum. Ketentuan hak atas bantuan hukum secara universal tanpa memandang kekayaannya hanya diberikan kepada anak yang yang menjadi tersangka dan terdakwa ${ }^{36}$ serta mereka yang diancam pidana diatas 15 tahun penjara atau diancam hukuman mati. ${ }^{37}$ Sayangnya hak ini kemudian bisa dikecualikan dengan mempertimbangkan faktor ketersediaan advokat. ${ }^{38}$

Jumlah advokat yang terdata di PERADI pada 2012, diperkirakan tidak lebih dari 25 ibu orang orang dimana mayoritasnya berada di Jawa khususnya Jakarta. ${ }^{39}$ Sementara jumlah penduduk Indonesia diperkirakan mencapai 253.609.643. ${ }^{40}$ Dengan perbandingan ini, tak heran bila akses terhadap bantuan hukum menjadi sulit untuk dipenuhi.

Situasi hak atas bantuan hukum juga tidak membaik paska disahkannya UU No 16 Tahun 2011 tentang Bantuan Hukum. Berdasarkan UU ini, untuk pertama kalinya Indonesia telah memiliki sistem penyelenggaraan bantuan hukum yang lebih tertata dan terintegrasi.

36 Lihat Pasal 23 UU No 11 Tahun 2012 tentang Sistem Peradilan Pidana Anak

37 Lihat Pasal 56 ayat (1) KUHAP

38 Lihat Penjelasan Pasal 56 ayat (1) KUHAP. Situasi ini juga menjelaskan bahwa jaminan hak atas bantuan hukum untuk anak yang menjadi tersangka dan terdakwa bisa jadi tidak terwujud dengan baik

39 Lihat Indonesia Masih Kurang Pengacara http://www.antarabali.com/berita/30500/indonesia-masihkurang-pengacara. Dikases pada 21 januari 2019. Lihat juga data Pusat Bantuan Hukum PERADI 2010.

40 Lihat Negara Dengan Penduduk Terbanyak di Dunia, RI Masuk 4 Besar http://finance.detik.com/read/2014/03/06/134053/2517461/4/negara-dengan-penduduk-terbanyak-didunia-ri-masuk-4-besar. Diakses pada 21 januari 2019. 
Namun demikian, jumlah organisasi bantuan hukum yang beroperasi dengan menggunakan dana bantuan hukum yang disediakan melalui UU Bantuan Hukum ini juga masih terbatas.

\section{Prospektif Pembaharuan Hukum Pidana dan Pemidanaan Yang Ada di Indonesia}

Pemidanaan terhadap pelaku kejahatan tidak dapat dipisahkan dari sistem pemidanaan yang dianut oleh sistem hukum di Indonesia. Bagian penting dalam sistem pemidanaan adalah menetapkan suatu sanksi. Keberadaannya akan memberikan arah dan pertimbangan mengenai apa yang seharusnya dijadikan sanksi dalam suatu tindak pidana untuk menegakkan berlakunya norma. Di sisi lain, pemidanaan itu sendiri merupakan proses paling kompleks dalam sistem peradilan pidana karena melibatkan banyak orang dan institusi yang berbeda. ${ }^{41}$

Penetapan sanksi hukum pidana seharusnya melakukan pendekatan rasional. Bila berdasar pada pendekatan rasional, maka kebijakan penetapan sanksi dalam hukum pidana tidak terlepas dari penetapan tujuan yang ingin dicapai oleh kebijakan kriminal secara keseluruhan, yakni perlindungan masyarakat untuk mencapai kesejahteraan. Penetapan tujuan ini, oleh Karl 0. Christiansen dikatakan sebagai prasyarat yang fundamental: "The fundamental prerequisite of defining a means, method or measure as rational is that the aim or purpose to be achieved is well defined" ${ }^{42}$

Menentukan tujuan pemidanaan pada sistem peradilan menjadi persoalan yang cukup dilematis, terutama dalam menentukan apakah pemidanaan ditujukan untuk melakukan

41 Puteri Hikmawati. (2011). Analisis Terhadap Sanksi Pidana Bagi Pengguna Narkotika, Jurnal, NEGARA HUKUM: Vol. 2, No. 2, November. Hal. 332

42 Karl 0. Christiansen, Some Considerations on the Possibility of a Rational Criminal Policy, sebagaimana dikutip dalam "Sistem Sanksi dalam Hukum Pidana” oleh Sholehuddin, ibid., hal. 118. 
pembalasan atas tindak pidana yang terjadi atau merupakan tujuan yang layak dari proses pidana adalah pencegahan tingkah laku yang anti sosial. Menentukan titik temu dari dua pandangan tersebut jika tidak berhasil dilakukan memerlukan formulasi baru dalam sistem atau tujuan pemidanaan dalam hukum pidana. Pemidanaan mempunyai beberapa tujuan yang bisa diklasifikasikan berdasarkan teori-teori tentang pemidanaan. ${ }^{43}$

Sejarah penegakkan hukum (pidana) telah mencatat bahwa sebagai negara hukum yang menganut Asas Legalitas, aparat penegak hukum Indonesia acapkali menerapkan Hukum Pidana secara berlebihan (overspanning van het straftrecht). Padahal, esensi Hukum Pidana adalah "obat terakhir" (ultimum remedium), yaitu sanksi hukum yang diterapkan apabila masih ada sanksi lain yang masih dapat digunakan. Dalam suatu sistem peradilan pidana yang terintegrasi (integrated criminal justice system), yang dimulai dari penyidikan, penuntutan, pemeriksaan, putusan pengadilan dan pelaksanaan eksekusi, pada akhirnya bermuara di Lembaga Permasyarakatan (lapas).

Oleh karena itu, maka sudah saatnya Indonesia sebagai negara hukum yang berbasis pada kedaulatan rakyat, dimana semangat penegakan hukum didasarkan pada Pancasila dan UUD 1945 yang didalamnya mengamanatkan adanya penegakan hukum secara berkeadilan dan berketuhanan serta didasarkan pada perlindungan bagi seluruh rakya Indonesia Harus mengegedepankan cara-cara yang memanusiakan manusia, adapun prospektif penegakan hukum pidana dan pemidanaan kedepan menurut penulis penting untuk di laksanakan adalah antara lain:

43 Puteri Hikmawati. Op.cit. Hal. 332-333 


\section{a. Pedekatan Restorative Justice dalam Penerapan Pemidanaan}

Pendekatan restorative justice diasumsikan sebagai pergeseran paling mutakhir dari berbagai model dan mekanisme yang bekerja dalam sistem peradilan pidana dalam menanggani perkara-perkara pidana pada saat ini, meskipun gerakan ini sudah dimulai di era tahun 1970 di Amerika Utara dan Eropa yang ditandai kehadiran Victim Offender Reconciliation Program di Ontario, kemudian discovery di Indiana dan Inggris ${ }^{44}$. bahkan 21 abad yang lalu sejak Yesus atau Isa Almasih menyebarkan Kitab Perjanjian Baru Otajil dan 14 abad lalu dengan kehadiran Islam, sudah diperkenalkan prinsip Restorative Justice yang masing-masing berupa prinsip "Cinta Kasih" dan "Qisos", yang diganti dengan "Diyat", yaitu rnengampuni" dan "memaafkan"45.

Berbagai definisi itu, tegas Prof. Dr. Marwan Effendy, SH, mensyaratkan adanya suatu kondisi tertentu yang menempatkan keadilan restoratif sebagai nilai dasar yang dipakai dalam merespon suatu perkara pidana. Dalam hal ini disyaratkan adanya keseimbangan fokus antara kepentingan pelaku dan korban, serta memperhitungkan pula dampak penyelesaian perkara pidana tersebut dalam masyarakat. ${ }^{46}$

Keadilan Restoratif sebagai bagian dari penyelesaiaan perkara pidana haruslah diberikan tempat dalam peraturan perundangan yang juga disertai dengan landasan/teori hukumnya.

44 Muladi makalah. (2012). Restorative Justice Dalam Sistem Peradilan Pidana disampaikan dalam seminar IKAHI, tgl 25 April. Hal. 1

45 Indriyanto Seno Adji. (2016). Makalah Dengan Judul "Sistem Hukum Pidana \& Keadilan Restoratif" Disampaikan Sebagai Pembicara pada Focus Group Discussion (FGD) dengan Tema "Pembangunan Hukum Nasional Yang Mengarah Pada Pendekatan Restorative Justice Dengan Indikator Yang Dapat Terukur Manfaatnya Bagi Masyarakat", pada hari Kamis, tanggal 01 Desember, Jam 10.00 - 12.30 WIB, di Ruang Aula Lt. 4 Gedung BPHN, Jalan Mayjen Sutoyo, Cililitan, Jakarta Timur. Hal. 12

46 Ibid, Hal. 12 
Restorative justice yang dimaksud adalah dalam konsep hukum pidana, bukan hukum perdata/privat dan juga harus dibedakan dengan mediasi dalam hukum perdata/privat, yang merupakan salah satu jenis Alternative Dispute Resolution (ADR $)^{47}$

Dalam Hukum Pidana, penghapusan suatu pemidanaan tentunya sangat erat kaitannya dengan proses dalam pengadilan (court settlement) mulai dari penyidikan, penuntutan, persidangan dan eksesekusi. Adapun mediasi penal (penal mediation) ${ }^{48}$, de mediation penale dalam Bahasa Perancis, merupakan salah satu bentuk alternatif penyelesaian sengketa di luar pengadilan (out of court settlement) atau biasa disebut sebagai alternative dispute resolution $(A D R)$, yang lazim digunakan dalam lingkungan kasus-kasus perdata. ${ }^{49}$ Meskipun serupa, tetapi kedua instrumen tersebut tidak selalu identik. Dalam konsep restorative justice bertujuan menghapus sama sekali penerapan pidana penjaranya, tetapi dalam konsep mediasi penal tidak sepenuhnya dapat menghapus penerapan pidana penjara terhadap delik-delik tertentu termasuk delik aduan, tetapi belum tentu terhadap delik lainnya, dan jika proses pidana tetap diteruskan hanya dapat dijadikan pertimbangan oleh hakim untuk meringankan hukumannya .

Bagir Manan, dalam tulisannya menguraikan tentang substansi "restorative justice" yang berisi prinsip-prinsip, antara lain: "Membangun partisipasi bersama antara pelaku, korban, dan kelompok masyarakat menyelesaikan suatu peristiwa atau tindak pidana. Menempatkan pelaku, korban, dan masyarakat sebagai "stakeholders" yang bekerja bersama dan langsung berusaha menemukan penyelesaian yang dipandang adil bagi semua pihak

47 Ibid, Hal. 13

48 Barda Nawawi Arief. (2010). Mediasi Penal Penyelesaian Pidana diluar Peradilan, Program Magister Ilmu Hukum, Pascasarjana UNDIP, hal. 1-3.

49 Indriyanto Seno Adji, Op.cit, Hal. 14 
(win-win solutions)".Terhadap kasus tindak pidana yang di lakukan oleh anak, maka restorative justice system setidak-tidaknya bertujuan untuk memperbaiki /memulihkan (to restore) perbuatan kriminal yang dilakukan anak dengan tindakan yang bermanfaat bagi anak, korban dan lingkungannya yang melibatkan mereka secara langsung (reintegrasi dan rehabilitasi) dalam penyelesaian masalah, dan berbeda dengan cara penanganan orang dewasa, ${ }^{50}$ yang kemudian akan bermuara pada tujuan dari pidana itu sendiri yang menurut Barda Nawawi Arief tujuan pemidanaan bertitik tolak kepada "perlindungan masyarakat" dan "perlindungan/pembinaan individu pelaku tindak. ${ }^{51}$

Dengan memahami pertimbangan keadilan restroratif justice tersebut, maka pendekatan penyelesaian yang mengedepankan pemulihan pidana kembali ke keadaan semula merupakan langkah yang lebih tepat, dari pada semata mengambil langkah represif berupa pidana penjara, sebagaimana dikatakan Prof. Dr. Marwan Effendy, SH, bahwa pendekatan restroratif justice sedang berkembang dan telah dilakukan di berbagai negara di Amerika Utara dan di Eropa. Sebagai alternatif dari kebijakan represif, dan sejalan pula dengan prinsip fundamental dalam UNCAC Tahun 2003 dan terakhir di Marrakech tahun 2011 yang tetap memprioritaskan upaya pengembalian uang negara yang dikorupsi (asset recovery) dan selanjutnya menempatkan penggunaan hukum pidana sebagai ultimum remedium atau sebagai upaya terakhir (last resort), dengan mengedepankan pendekatan restorative justice. Sebagai konsekuensi yuridis dari pendekatan tersebut. ${ }^{2}$

50 DS. Dewi, Restorative justice, Diversionary Schemes and Special Children's Courts in Indonesia. Artikel tidak diterbitkan, hal. 1.

51 Barda Nawawi Arief. (2008). “Bunga Rampai Kebijakan Hukum Pidana”. Jakarta: PT. Kencana Prenada Media Group. Hal. 98.

52 Indriyanto Seno Adji, Op.cit.. Hal. 10 


\section{b. Pendekatan Ultimum Remedium dalam Penerapan Pemidanaan}

Hoefnagels, telah mengingatkan pentingnya mempertimbangkan berbagai faktor untuk melakukan kriminalisasi agar tetap menjaga dalil ultimum remedium dan tidak terjadi over criminalization antara lain 53 :

1. Jangan menggunakan Hukum Pidana dengan cara emosional;

2. Jangan menggunakan hukum pidana untuk mempidana perbuatan yang tidak jelas korban atau kerugiannya;

3. Jangan menggunakan hukum pidana, apabila kerugian yang ditimbulkan dengan pemidanaan akan lebih besar dari pada kerugian oleh tindak pidana yang akan dirumuskan;

4. Jangan menggunakan hukum pidana apabila tidak didukung oleh masyarakat secara kuat;

5. Jangan menggunakan hukum pidana apabila penggunaannya;

6. diperkirakan tidak akan efektif;

7. Hukum pidana dalam hal-hal tertentu harus mempertimbangkan secara khusus skala prioritas kepentingan pengaturan;

8. Hukum pidana sebagai sarana represif harus didayagunakan secara serentak dengan sarana pencegahan.

Hukum Pidana dengan sanksi yang keras dikatakan mempunyai fungsi yang subsider artinya apabila fungsi hukum lainnya kurang maka baru dipergunakan Hukum Pidana, sering juga dikatakan bahwa Hukum Pidana itu merupakan ultimum remedium. Ultimum remedium merupakan istilah hukum yang biasa dipakai dan diartikan sebagai penerapan sanksi pidana

53 G.P. Hoefnagels. (1973). “The Other Side of Criminology”. Holland: Kluwer Deventer. Hal. 99, 102-106. 
yang merupakan sanksi pamungkas (terakhir) dalam penegakan hukum. Sudikno Mertokusumo ${ }^{54}$ mengartikan bahwa ultimum remedium sebagai alat terakhir.

Berpijak kepada alasan tersebut, bisa diartikan bahwa pemidanaan dimaksudkan sebagai alternatif terakhir penghukuman suatu perbuatan pidana. Dengan kata lain, ultimum remedium itu mensyaratkan terlebih dahulu upaya pemberian sanksi lain (non-penal), berupa ganti rugi, denda, peringatan atau hal lainnya sebelum digunakannya sarana hukum pidana berupa penjara (badan). Oleh karena itu, maka kedepan desain hukum pidana Indonesia harus diarahkan mengikuti sistem pemidanaan modern.

\section{c. Revisi Kitab Undang-Undang Hukum Pidana (KUHP) dan Kitab Undang-Undang Hukum Acara Pidana (KUHAP)}

Penetapan sanksi dalam suatu perundang-undangan pidana bukanlah sekedar masalah teknis perundang-undangan semata, melainkan ia merupakan bagian yang tidak terpisahkan dari substansi atau materi perundang-undangan itu sendiri, artinya, masalah penalisasi, depenalisasi, kriminalisasi dan dekriminalisasi harus dipahami secara komprehensif dengan segala aspek persoalan substansi atau materi perundang-undangan pada tahap kebijakan legislasi. ${ }^{55}$

Hal yang sangat penting untuk menata sistem pidana dan pemidanaan di indonesia dimulai dari memperbaiki legal substansi daripada ketentuan-ketentuan pidana dalam melakukan Revisi Kitab Undang-Undang Hukum Pidana (KUHP) dan Kitab Undang-Undang Hukum

54 Sudikno Mertokusumo. (2006). "Penemuan Hukum Sebuah Pengantar”. Yogyakarta: Liberty, Hal. 128

55 Sholehuddin. (2003). "Sistem Sanksi dalam Hukum Pidana". Jakarta: PT RajaGrafindo Persada, Cetakan pertama, September. Hal. 5 
Acara Pidana (KUHAP) hal yang pentig untuk dilakukan adalah penulis mendorong agar pemerintah dan DPR membuka luas partisipasi masyarakat selain membuka seluruh perdebatan-perdebatan dalam pembahasan Rancangan KUHAP. mendorong pemerintah untuk menguji ulang beberapa ketentuan dalam naskah RUU KUHAP. Sedangkan untuk Rancangan KUHP, penulis mendorong agar rancangan yang sudah ada dipelajari ulang termasuk perlu memikirkan kembali model kodifikasi penuh yang di gagas dalam rancangan tersebut.

\section{d. Reformasi Kelembagaan Lembaga Penegak Hukum}

Hukum Pidana adalah hukum yang mengatur tentang pelanggaran dan kejahatan terhadap kepentingan umum. Pelanggaran dan kejahatan tersebut diancam dengan hukuman yang merupakan penderitaan atau siksaan bagi yang bersangkutan. ${ }^{56}$ Untuk tegaknya hukum pidana maka diberilah kewenangan kepada Lembaga Kepolisian, Kejaksaan, dan Pengadilan. dimana para pelaku kejahatan atau penjahat yang umumnya berasal dari kalangan ekonomi lemah brutal, dan marginal. Karena itu tidak berlebihan jika kejahatan dianggap sebagai masalah sosial yang pada umumnya bersumber dari masalah kemiskinan.

Sebagaimana kita ketahui aparat penegak hukum seperti Hakim, Jaksa dan Polisi merupakan Pegawai Negeri Sipil. Di banyak negara, aparat penegak hukum merupakan pejabat negara yang dibedakan dengan Pegawai Negeri Sipil. Oleh karena itu melalui Reformasi Birokrasi inilah sistem reward dan kesejahteraan aparat penegak hukum akan ditingkatkan sehingga sesuai dengan tuntutan kebutuhan hidup yang layak dan tuntutan lain dalam menjalankan profesi dengan, integritas tinggt, akuntabel dan terhormat. Lebih jauh lagi melalui Reformasi Birokrasi aparat penegak hukum ini diharapkan akan tercipta suatu organisasi modern yang

\footnotetext{
56 Yulies Tiena Masriani. (2006). “Pengantar Hukum Indonesia”. Jakarta: Sinar Grafika, Cet II, Hal. 60
} 
mengutamakan pelayanan publik dalam penegakan hukum,melalui perubahan sistem yang mencakup pembenahan kelembangaan, bisnis proses dan sumber daya manusia.

Selain itu, peran krusial advokat, polisi, jaksa, dan hakim sebagai kuartet penegak hukum untuk mencegah penerapan hukum pidana yang berlebihan juga perlu diatur dalam peraturan setingkat Undang-Undang tentang Mediasi Penal, khususnya untuk beberapa kategori tindak pidana tertentu. Yaitu, suatu alternatif penuntutan yang memungkinkan penyelesaian secara negosiasi antara pelaku tindak pidana dan korban. Dengan perangkat hukum yang baik dan penegak hukum yang berintegritas, bukan mustahil suatu saat nanti di Indonesia akan tumbuh budaya hukum restoratif, sehingga masyarakat bukan menjadi takut untuk dihukum, melainkan "malu" untuk melakukan kejahatan. ${ }^{57}$

\section{Kesimpulan}

Penerapan hukum pemidanaan di Indonesia saat ini, masih meninggalkan beberapa catatan penting antara lain; banyak Terjadinya Over Criminalization dan banyaknya terjadi Dekonstruksi Pidana dan Pemidanaan di Indonesia dimana dekonstruksi itu antara lain; Pertama, Terjadinya Over Kapasitas Lapas dan Rutan, kedua, Pengaturan Hukuman Mati yang Sangat Massif; ketiga, Kebijakan Hukum Yang Over Pada Penghinaan Di Media Sosial; keempat, Dalam Penyidikan Kriminal Penyidik Mencari Bukti Dengan Kejahatan (penyiksaaan); kelima, Inkonsistensi Hak Atas Perkara Cuma-Cuma (prodeo).

Prospektif Pembaharuan Hukum Pidana dan Pemidanaan Yang Ada di Indonesia harus didasarkan pada beberapa hal, antara lain: Pedekatan Restorative Justice dalam Penerapan

57 Albert Aries. (2019). "Penerapan Hukum Pidana yang Berlebihan”. Dilansir dari https://news.detik.com/kolom/d4163780/penerapan-hukum-pidana-yang-berlebihan . Diakses pada 28 maret 2019 
Pemidanaan; Pendekatan Ultimum remedium dalam penerapan pemidanaan; Reformasi Kelembagaan Lembaga Penegak Hukum; dan Revisi Kitab Undang-Undang Hukum Pidana (KUHP) dan Kitab Undang-Undang Hukum Acara Pidana (KUHAP).

\section{Referensi}

Andi Hamzah dan Siti Rahayu. (1986). Suatu Tinjauan Ringkas Sistem Pemidanaan Di Indonesia, Akademik Pressindo, Jakarta.

Anggara dkk, (2015). Laporan Situasi Reformasi Hukum Di Sektor Pidana Indonesia "Catatan

Di 2014 Dan Rekomendasi Di 2015”, Jakarta: Institute for Criminal Justice Reform.

Brian Z. Tamanaha, 'A Concise Guide of the Rule of Law' dalam Gianluigi Palombella dan Neil Walker, eds., Relocating the Rule of Law Hart Publishing 2009.

Barda Nawawi Arief. (2008). Bunga Rampai Kebijakan Hukum Pidana, Jakarta: PT. Kencana

Prenada Media Group.

Barda Nawawi Arief. (2010). Mediasi Penal Penyelesaian Pidana diluar Peradilan, Semarang:

Program Magister Ilmu Hukum, Pascasarjana UNDIP.

Ekaputra, Mohammad dan Abul Khair, (2010). Sistem Pidana Di Dalam KUHP Dan Pengaturannya Menurut Konsep KUHP Baru, Medan: USU Press.

G.P. Hoefnagels. (1973). The Other Side of Criminology, Kluwer Deventer, Holland.

Nina Persak. (2007). Criminalising Harmful Conduct: The Harm Principle, Its Limits and Continental Counterparts, Springer.

Sholehuddin. (2003). Sistem Sanksi dalam Hukum Pidana, Jakarta: PT RajaGrafindo Persada, Cetakan pertama, September.

Sudikno Mertokusumo. (2006). Penemuan Hukum Sebuah Pengantar, Yogyakarta: Liberty, Yulies Tiena Masriani. (2006). Pengantar Hukum Indonesia, Cet II, Jakarta: Sinar Grafika. 


\section{Jurnal, Makalah}

DS. Dewi, Restorative justice, Diversionary Schemes and Special Children's Courts in Indonesia. Indriyanto Seno Adji. (2016). Makalah Dengan Judul “Sistem Hukum Pidana \& Keadilan Restoratif" Disampaikan Sebagai Pembicara pada Focus Group Discussion (FGD) dengan Tema "Pembangunan Hukum Nasional Yang Mengarah Pada Pendekatan Restorative Justice Dengan Indikator Yang Dapat Terukur Manfaatnya Bagi Masyarakat", pada hari Kamis, tanggal 01 Desember, Jam 10.00 - 12.30 WIB, di Ruang Aula Lt. 4 Gedung BPHN, Jalan Mayjen Sutoyo, Cililitan, Jakarta Timur

Muladi. (2012). makalah Restorative Justice Dalam Sistem Peradilan Pidana disampaikan dalam seminar IKAHI, tgl 25 April.

Marthen H. Toelle. (2015). Kriminalisasi Berlebih (Overcriminalization) Dalam Kriminalisasi Korupsi, Jurnal Refleksi hukum, Vol. 9. No. 2.

Puteri Hikmawati. (2011). Analisis Terhadap Sanksi Pidana Bagi Pengguna Narkotika, Jurnal, NEGARA HUKUM: Vol. 2, No. 2, November.

Titin anidyajati, dkk. (2015). Konstitusionalitas Norma Sanksi Pidana sebagai Ultimum Remedium dalam Pembentukan Perundang-undangan, Jurnal Konstitusi, Volume 12, Nomor 4, Desember. 